\title{
POÉTICAS DO TRADUZIR $A$, NA E PARA A CHINA: UMA PROPOSTA
}

\author{
Júlio Reis Jatobá ${ }^{1}$ \\ -Universidade de Macau, Macau, China
}

\begin{abstract}
Resumo: Neste artigo apresentaremos e discutiremos alguns pensares do traduzir na e $a$ China que nos conduzam à proposição de uma "poética do traduzir na China" e de uma "poética de traduzir $a$ China". Para cumprir este objetivo, traçaremos um breve panorama das perspectivas históricas e filosóficas das línguas chinesas e da literatura na China, bem como a visão de autores, tradutores e acadêmicos chineses e brasileiros sobre traduzir literatura da ou para a China. Iniciaremos nossa discussão com uma contextualização sobre a necessidade de (re)considerar as noções de língua, literatura e tradução nos tempo-espaços e espaços-geográficos da civilização chinesa para, em seguida, discorrer sobre a aplicação das noções de chinesidade (Yang Lian), traduto(meio)logia e traição criativa (Xie Tianzhen), paralaxe tradutória (Jatobá) e, ainda, da metáfora do Taotie 饕䬸 (Ricardo Portugal), como alternativas para propor uma "poética do traduzir $a$, na e para a China".
\end{abstract}

Palavras-chave: Poética do Traduzir; Literatura Chinesa; Tradução de Poesia Chinesa; Medio-translatology; Paralaxe Tradutória

\section{A POETICS OF TRANSLATING IN, TO AND FROM CHINA: A PROPOSAL}

\begin{abstract}
In this article we will present and discuss some thoughts on translating in and to China in order to lead us to propose a "poetics of translating in China" and a "poetics of translating the China". To fulfill this objective, we will provide a brief overview of the historical and philosophical perspectives of Chinese languages and literature in China, as well as the views of Chinese and Brazilian authors, translators and scholars on translating literature to or from China. We will begin our discussion
\end{abstract}


with a contextualization of the need to (re) consider the notions of language, literature, and translation in the time and space and geographical-spaces of Chinese civilization, and then discuss the application of the notions of Chineseness (Yang Lian), Medio-translatology and creative treason (Xie Tianzhen), the parallax translation (Jatobá) and also the Taotie 饕 䬸 metaphor (Ricardo Portugal), as alternatives to propose a "poetic of translating in, to and from China".

Keywords: Poetics of Translating; Chinese Literature; Translation of Chinese Poetry; Medio-Translatology; The Parallax Translation

\section{中文譯入與譯出的詩意思維初探}

摘要

本文將介紹並討論部分關於中文譯入譯出的思想, 並基於上述 思想提出” 中文譯入的詩意思維” 及” 中文譯出的詩意思維” 的理論。為此, 本文將簡要論述中國語言文學的歷史和哲學觀 點以及中國和巴西兩國的作家、翻譯、學者關於中國的文學翻 譯（譯入及譯出）的觀點。我們將在中華文明的時間與空間的 雙重背景下, （重新）考量我們對語言、文學及翻譯的定義, 探討如何應用” 中國性及中文性（楊煉）”、”譯介學”、” 創造性叛逆（谢天振）”、”翻譯視差（Jatobá）”及”饕䬸 （Ricardo Portuga1）”的概念，並提出”中文譯入與譯出的 詩意思維”的理論。

關鍵詞：詩意翻譯，中國文學，中詩翻譯，譯介學，翻譯視 差

语不惊人死不休

杜甫(712-770)

sem quietude morrerei se as minhas palavras espanto não causem

$\mathrm{Du} \mathrm{Fu}(712-770)$ 


\section{Sobre língua, literatura e tradução nas Chinas ${ }^{1}$}

De maneira redutora, mas de grande valia para a nossa discussão, a história da tradução na China desenvolve-se notavelmente em dois momentos de ideologias tradutórias, ambas incitadas e despertadas por duas diferentes necessidades e direções: traduzir $o$ de fora para dentro e traduzir o de dentro para fora. Em nossa argumentação, o traduzir de fora para dentro refere-se ao monumental projeto de tradução do cânone budista, a saber, em seus três diferentes tipos de escritas: sutra 經 (jīng), os ensinamentos do Buda Gautama Sakyamuni; vinaya 律 (lü), as regras da disciplina monástica e, de modo sumário, as regras da moralidade budista e a lei do cânone; sastra 論 (lùn), as exposições o ensino do sutra (cf. Cheung 1). Convém mencionar que, assim como salienta Cheung (49), no contexto do "projeto budista" de tradução, o termo tradução dos sutras é usado como maneira genérica para se referir ao projeto de tradução do cânone budista como um todo. Em nossa discussão não entraremos no domínio da análise das traduções dos sutras per se, por isso, usaremos aqui o "projeto budista" de tradução como fio condutor para analisar eventos e elementos que, de uma perspectiva histórica dos modi operandi e das filosofias da tradução na China, contribuam para especular sobre uma "poética do traduzir" chinesa.

Por outro lado, o traduzir de dentro para fora é o que o teórico chinês Xie Tanzhen trata como o atual contexto chinês das ideologias inerentes às funções da tradução (Xie 译介学 [traduto(meio) logia]). Vale destacar que, no primeiro caso, trata-se de um projeto pioneiro e sem precedentes na história que durou aproximadamente de meados do século II até aproximadamente o começo do século XII (Cheung 49). Porém, no segundo caso, o "atual contexto

\footnotetext{
${ }^{1}$ Usamos o plural com a intenção de dar ao leitor uma visão panorâmica da China como longa civilização irradiadora de ritos, artes e filosofia em seus diferentes tempo-espaços e espaços-geográficos. Em relação ao uso de caracteres chineses tradicionais ou simplificados, mativemos as grafias originais dos textos-fonte.
} 
chinês" refere-se aos séculos XX e XXI, com atenção especial à formação da República Popular da China (1949) e, sobretudo, à ascensão e afirmação da China como principal contraponto político, econômico e cultural ao estableshiment ocidental.

Sem dúvida, explorar de maneira pormenorizada os conceitos e funções da tradução nestes dois tempo-espaços é de fundamental importância para um entendimento de uma "história do traduzir" e, consequentemente, de "poéticas do traduzir" na China. Porém, infelizmente, esta pormenorização extrapolaria a síntese necessária que precisaremos para cumprir os objetivos deste artigo. Desse modo, para buscarmos outras linhas que nos conduzam a uma "poética do traduzir na China" ou uma "poética de traduzir a China", temos que entender duas grandes forças operantes na construção do discurso de uma "chinesidade" literária. Estas são, respectivamente, "as determinações particulares da língua e da cultura chinesa (a sua diferença com as outras línguas e culturas)" e "os processos de verdade artística que vêm de, e voltam para, este particular espaço lingüístico-cultural" (Pozzana; Russo 9). Estas "determinações" e "processos de verdade artística", elaboradas inicialmente pelo poeta chinês Yang Lian 楊煉 e, nomeadamente, cunhadas pelo próprio poeta como zhongguoxing e zhongwenxing ${ }^{2}$, são, a nosso ver, lados opostos, mas complementares da literatura chinesa.

Assim como defendemos no artigo "Poesia e (in)traduzibilidade na língua chinesa", as relações de complementariedade que têm como fruto uma proposta de "chinesidades" estão diretamente ligadas às particularidades da língua chinesa e de seus processos de verdade artística. Porém, estendemos a este debate a proposta de uma "chinesidade" histórico-literária. Para isso, retornamos à ideia de que o entendimento de uma "poética do traduzir na ou $a$ China" só é possível com a consciência da(s) língua(s) chinesa(s)

2 Zhongguoxing 中國性 e zhongwenxing 中文性, podem ser respectivamente traduzidos como "característica da China" e "característica da 'língua-cultura' chinesa". Neste artigo, usaremos o singular "chinesidade" para nos referirmos a zhongguoxing e "chinesidades" para zhongwenxing. 
em relação a seus tempo-espaços e em seus espaços-geográficos, pois "[f]alar sobre língua chinesa implica falar de toda uma tradição e transformação cultural da China; assim como falar de sua formação territorial e de sua força como polo irradiador poético, filosófico, linguístico e tecnológico" ("Poesia e (in)traduzibilidade na língua chinesa” 213).

Se a definição do tempo-espaço da(s) língua(s) chinesa(s) é crucial, o mesmo se aplicaria à(s) literatura(s) chinesa(s)? A China, numa perspectiva histórico-literária, sempre consumiu-se a si mesma, fruto não apenas das complexidades e peculiaridades da lingua(gem) chinesa e de suas formas literárias, mas, da igualmente complexa noção clássica de "arte" como um subproduto da tradição literária ${ }^{3}$ Como alerta Sinedino ("As Dimensões do Cânone VII" 133) em comentário à sua tradução pioneira de Classificação dos Poetas (Shipin 詩品), de Zhong Rong 鍾嶸 (468?-518?),

'Literatura', para os chineses antigos, incluía toda a gama de textos produzidos pela burocracia e obras de ocasião, tais como memoriais ao imperador, pareceres, despachos, eulogias, epitáfios, etc. Neste sentido, não havia diferença de fundo entre um poema e uma carta para um parente, pois o tipo de linguagem e de acabamento literário que se exigia de ambos era basicamente o mesmo. Na retórica chinesa, era muito importante demonstrar conhecimento de obras clássicas, que não apenas incluía o cânone ortodoxo e as obras dos mestres, mas também as narrativas das crónicas históricas oficiais e as colectâneas literárias mais famosas (seja pela autoridade da pessoa seja pelos seus dotes literários). ${ }^{4}$

\footnotetext{
${ }^{3}$ Para um extensivo e detalhado panorama sobre a noção e funções da arte na China antiga, encorajamos a leitura da série de artigos e traduções comentadas intitulada "As Dimensões do Cânone", de autoria do eminente sinólogo e tradutor Giorgio Sinedino. A referida série encontra-se publicada na Revista de Cultura do Instituto Cultural de Macau, a partir da edição número 46. Os artigos e traduções estão disponíveis online em http://www.icm.gov.mo/rc/4.

${ }^{4}$ Comentário de Sinedino em relação à sua tradução pioneira de Classificação dos Poetas (Shipin 詩品), de Zhong Rong 鍾嶸 (468?-518?).
} 
Gu Kaizhi 顧愷之 (344?-406?), um dos mais importantes pintores da tradição chinesa e membro do "Jardim Literário" de Jin, em “O Jardim Literário” (Wen yuan 文苑), sintetiza bem a dimensão da hierarquia do literário:

É ao promover a doutrinação moral que a tradição literária se consuma; somente o Sábio espelha e dá corpo aos mais elevados princípios. 'Se um texto não tem qualidades literárias, mesmo que comece a circular entre os eruditos, nunca longe irá', eis um provérbio consagrado nas crónicas antigas. Logo, as águas do rio Luo amornam-se, eventos auspiciosos ocorrem, com ideogramas azuis avulta a Magna Causa. Uma montanha de jardins literários pulula com signos escarlates e tomos dourados que, reunidos, integram os feitos imperiais. Não muito depois, a prática de registar símbolos sobre seda ou bambu desenvolveu-se subitamente, palavras gravadas sobre instrumentos musicais de metal e pedra tornaram-se mais comuns. A doutrinação do Rei transformou os costumes e hábitos do povo, de maneira que o preito aos valores de piedade filial e de respeito aos superiores se infundiu na moralidade das gentes. Coube à escrita, à tradição literária disciplinar a relação entre Qian e Kun tal como a urdidura é para a trama, ordenando e hierarquizando as culturas dos povos do meio e dos povos de fora: tamanha a sua importância, duradoura a sua significância pelos tempos! (Gu Kaizhi em tradução de Sinedino ${ }^{5}$ )

O exposto por Gu Kaizhi traz a complexidade da literatura chinesa e sua relação íntima e hierarquizante sob as outras "artes", sobretudo a pintura. Em "Ut Pictura Poesis: Intuições para a Experiência Chinesa - Um Esboço”, Sinedino, ao desenvolver sua argumentação sobre "pinturas que pintam poemas" (122) e "como uma pintura, deve ser poesia: ut pictura poesis", expõe:

${ }^{5}$ Sinedino "O Poeta-Pintor no Seu Meio: Um Relance sobre Gu Kaizhi - Selecção de Fontes Biográficas e Ensaios" 
[...] a própria hierarquia das 'artes' chinesas obriga um pintor a estar vinculado a uma comunidade organizada em torno da escrita poética [...] O que merece mais atenção, contudo, é a possibilidade de a pintura se irmanar à poesia enquanto prática artística ou de ambas se subsumirem a um único sistema de apreciação estética (122).

Porém, para orientar nossa busca por "uma poética do traduzir", delimitaremos aqui a complexidade das questões desenvolvidas por Sinedino à relação caligrafia-poesia e poesia-imagem. Para encerrar, por ora, nossa reflexão sobre as relações entre literatura e as "artes", é importante clarificar que, no desenvolvimento de nossa argumentação, "pintura" não será tomada em seu sentido amplo, mas, sim, reduzida às questões da visualidade e imagética inerentes à poesia chinesa e, consequentemente, ao espaço desta discussão em sua tradução/transcriação ao português. Assim sendo, vale, por fim, estabelecer as diferenças entre "pintura" e "caligrafia":

Diferentemente da pintura em sentido amplo - que inclui o revestimento de paredes, o trabalho decorativo de objetos, etc. -, a caligrafia nunca fora um ofício relegado para a classe subalterna dos artesãos. Por ser uma habilidade comummente exigida de todo burocrata, a caligrafia é um subproduto do trabalho de repartição, um elemento que atribui identidade ao grupo de funcionários a servir uma administração hierarquicamente unificada e centralizada. Partindo desse patamar, vemos por que razão a caligrafia adquiriu um estatuto mais elevado ao legitimar-se como passatempo digno da elite letrada. (ibidem 123)

Exposta a complexidade de classificar uma "literatura chinesa" ou a relação entre as "artes" chinesas como um continuum de passado e presente, é necessário agora voltar à consideração sobre a China consumir-se a si própria, pois tal fato incita uma reflexão sobre o local da literatura traduzida e da literatura estrangeira na 
China. Isso posto, qual é o espaço da literatura traduzida na China? Há uma "identidade" da "literatura traduzida" ou da "literatura estrangeira"? Neste sentido Zhang (83) expõe:

A identidade da 'literatura traduzida' tem sido uma questão ambígua e opaca no contexto literário chinês, devido ao fato de que a literatura traduzida na China era tida como uma transformação meramente técnica e simples a nível linguístico, daí que a literatura traduzida não passava de ser uma parte da 'literatura estrangeira'. Nesta classificação, as complexas atividades de tradução foram simplificadas, sendo descartadas suas próprias características distintas.

Convém explicitar que, para entender a ambiguidade e opacidade da "identidade da literatura traduzida" no contexto literário chinês, é importante citar que a formação de um discurso do para que, para quem e, principalmente, como traduzir literatura, é iniciada pela tradução de obras de filosofia e de pensadores estrangeiros em meados do século XIX, ao passo que a tradução de prosa estrangeira começa a ganhar mais espaço ao fim do século XIX. Já com relação à poesia, a nova poesia chinesa nasce em um contexto de rompimento com o "clássico" durante o Movimento de Quatro de Maio 五四運動 e um dos marcos para a entrada e aceitação de poesia não-chinesa foi a tradução de Garcia Lorca ao chinês.

É nessa contextura de opacidade e de ambiguidade da "literatura traduzida" na China que discutiremos, na próxima seção, uma recente e crescente perspectiva teórica para a tradução de literatura da (e para a) China: a proposição de que a traduto(meio)logia seja um meio para confrontar e desenvolver academicamente a problemática do discurso segundo o qual a "literatura traduzida" na China seria reduzida a mera parte da "literatura estrangeira", podendo e devendo a traduto(meio)logia - a partir da premissa de que $o$ ato tradutório e o pensar a tradução e a literatura extrapolam, inevitavelmente, os limites da forma linguística - inserir, localizar 
e pleitear a tradução de literatura da ou para a China dentro da perspectiva de uma literatura-mundo.

\section{Traduto(meio)logia e traição criativa}

Certamente, para melhor entendermos o que tem sido discutido sobre a tradução literária na China, encorajamos leituras paralelas sobre autores e tradutores chineses que desenvolveram as bases do pensar tradução literária na China moderna. Além de terem sido percursores da introdução de literatura traduzida na China, tais autores são as bases do que tem vindo a formar a "escola chinesa" de tradução literária ${ }^{6}$. As bases desses pensamentos e discursos, que vão desde Yan Fu 严复 (1854-1921) e sua postulação das dificuldades da tradução fundamentadas na tríade Xin Da Ya (信达 雅: xin, “fidelidade"; da, "fluidez"; ya, "elegância”)", passando por Lu Xun鲁迅 (1881-1936) e, em tempos mais recentes, Mao Dun 茅盾 (1922) e Xu Yuanchong 许渊冲 (1921), são intertextos fundamentais na construção de nossa proposta de uma poética do traduzir da (e para a) China (cf. Jatobá "Poesia e (in)traduzibilidade na língua chinesa").

Dito isso, passamos a tratar da questão da traduto(meio)logia e da traição criativa. Inicialmente, valendo-nos da noção de "traição criativa" no ato tradutório, neste artigo traduzimos o neologismo

6 Para um breve panorama sobre a tradução de literatura chinesa à língua portuguesa, recomendamos a leitura do "Dossiê: Tradução e Poesia Chinesa" (org. Raquel Abi-Sâmara), disponível em Scientia Traductionis.13 (2013): 197280. https://periodicos.ufsc.br/index.php/scientia/issue/view/2016.

${ }^{7}$ A questão das três dificuldades da tradução 譯事三難: 信達雅 desenvolvida por Yan Fu tem sido encarada por alguns estudiosos como uma releitura dos "três princípios básicos da boa tradução" sugeridos por Alexander Fraser Tytler (1791). Refutamos esta ideia no sentido de que dentro de seu tempo-espaço a proposição Xin $D a Y a$ não deve ser vista como uma "prescrição tradutória" para a reprodução "fiel" do original, mas sim como um proto-pensamento da discussão do espaço do literário na tradução não-literária. 
译介学 (yì jiè xué) ${ }^{8}$, proposto por Xie Tianzhen em 1999, como traduto(meio)logia. Jogamos aqui com o dúbio sentido de meio que, além de quebrar a tradutologia ao meio, pode significar intermédio/intermediário ou, em tradução reversa, meio (中) pode ser alusivo ao Império do Meio, um dos nomes usados ao longo da história para se referir à China.

Mesmo no original, o neologismo de Xie - que também dá nome ao livro em que foi proposto - causa estranheza ao leitor chinês não apenas por "quebrar" a palavra "tradutologia", mas, ainda mais importante, por chamar a atenção ao status da tradução literária na China. Assim sendo, além de tentarmos reproduzir a estranheza "sonora" e "visual" do neologismo, a nossa tradução seguiu outras duas lógicas. A primeira, tentar chamar a atenção para um dos debates centrais no meio acadêmico da tradução de literatura na China: em que meio se encontra um pensar tradução que discuta e integre a guinada cultural na tradução e a guinada da tradução nos estudos culturais. A segunda, de caráter ainda menos óbvio que a primeira, é incitar uma reflexão para a falta de critérios no meio acadêmico chinês sobre literatura estrangeira versus literatura traduzida dentro da perspectiva de uma literatura-mundo.

Para Xie, a contribuição do uso do termo traduto(meio)logia reside no fato de ele permitir sua distinção em relação aos "estudos da tradução convencionais" por não focar-se na transformação linguística, mas, dentro da macroperspectiva da literatura comparada, aumentar o intercâmbio, disseminação, aceitação e influência de traduções e de maneiras de traduzir em diferentes espaços culturais. Nesse sentido, a traduto(meio)logia extrapola os limites linguísticos e, por sua natureza, evita envolver-se em questões sobre fidelidade. Para isso, a traduto(meio)logia toma as traduções deixadas pela história como fato consumado e dedica-se a investigar e analisar os fenômenos linguísticos nessas traduções como recursos

${ }^{8}$ Literalmente, 译学 (yì xué) significa Estudos da Tradução ou Tradutologia e 介 (jiè) estar entre. 
para estudos literários ou culturais. (Xie "Medio-Translatology: A New Area of Comparative Literature" 43).

Neste sentido, dentro do contexto literário, um dos frutos do pensar traduto(meio)lógico é o de considerar a tradução, dentre todas as suas possibilidades, como espaço de reprodução, criação ou apropriação estética. Ao contrário da perspectiva Xin $\mathrm{Da} Y a$ (Yan Fu), a traduto(meio)logia não se atém a uma fidelidade estática ou, ainda, não se atém ao texto-fonte como "fonte pura". Ao contrário, para Xie, a tradução literária pode ser construída por traições criativas.

Já em 1987, no Manual de Literatura Comparativa Chinesa e Ocidental (中西比较文学手册), o termo traição criativa aparece:

Há três aspectos para o seu significado: um refere-se ao 'mal-entendido' dos leitores modernos a obras anteriores, por exemplo, contrariamente à intenção original da obra, o Gulliver's Travels de Swift e o Robinson Crusoe de Defoe são lidos como um trabalho infantil em muitos países hoje; o segundo é para atender aos gostos dos leitores nacionais e alterar os trabalhos estrangeiros em violação da intenção original, como a adaptação de Pound da poesia chinesa; o terceiro refere-se às compreensões erradas devido à limitação da linguagem na tradução, resultando em 'traição criativa'. ${ }^{9}$

Porém, é em 1999, a partir duma releitura de Robert Escarpit, em Sociologie de La Littétature, que Xie desenvolve a aplicação do conceito traição criativa como recurso e elemento de análise para tradução de literatura dentro da perspectiva da traduto(meio) lógica. Para Escarpit (137):

9 Tradução de Yang Gen Di. Texto original: 其含义有三个方面: 一指现代读 者对以前作品的 “误解” , 比如, 同作品的原意相反, 期威夫特的《格列 夫游记》和笛福《鲁滨逊漂流记》今天在许多国家被当作儿童作品阅读; 二 是指为迎合本国读者趣味, 对外国作品进行违反原作本意的改动, 如庞德对 中国诗的改编; 三是指在翻译中由语言的局限而导致理论上的错误，产生 “ 创造性叛逆”。 
If you are receptive to the idea that translation is always creative treason, then you may have a solution to the intriguing problem of translation. To hold that translation is treason is due to the fact that the original work is put into an unexpected reference system (language); and that translation is also creative means that the original work is given a new look and comes into contact with new readers; translation gives the original work a second life, ...

Xie (13-4) desenvolve:

Se a criatividade na tradução literária mostra um esforço subjetivo do tradutor para abordar e reproduzir o trabalho original com a sua própria criação artística, então a traição na tradução literária reflete um desvio objetivo do texto de chegada contra o texto original causado pelo tradutor para alcançar um certo desejo subjetivo, mas isso é apenas teoricamente: na tradução literária real, a criatividade e a traição são inseparáveis uma da outra, são harmoniosas. Portanto, o sociólogo literário francês Escarpit propôs 'traição criativa' e que a tradução é sempre uma traição criativa. ${ }^{10}$

Para Xie, a traição criativa pode ser alcançada, analisada ou manifestada em quatro formas de tradução. A primeira, tradução personalizada, incluiu, entre as suas variadas manifestações, a escolha consciente ou subjetiva do tradutor entre, por exemplo, domesticar ou estrangeirizar uma obra. Como aponta Xie, esta é uma traição criativa inevitável e que lida com as complexas relações de

\footnotetext{
10 Tradução de Yang Gen Di. Texto original: “如果说，文学翻译中的创造性 表明了译者以自己的艺术创造才能去接近和再现原作的一种主观努力, 那么 文学翻译中的叛逆性, 就是反映了在翻译过程中译者为了达到某一主观愿望 而造成的一种译作对原作的客观背离。但是这仅仅是从理论上而言，在实际 的文学翻译中, 创造性与叛逆性其实是根本无法分隔开来的, 它们是一个和 谐的有机体。因此, 法国文学社会学家埃斯卡皮提出了一个术语 “创造性叛 逆”，并说翻译总是一种创造性叛逆”。
} 
conhecimento de mundo do tradutor, tal como as limitações de conhecimento histórico-cultural, as diferenças entre valores estéticos, a psicologia nacional e a influência de tendências políticas.

A segunda forma, tradução errada e tradução incompleta, é subclassificada como consciente ou inconsciente. Uma tradução errada inconsciente deve-se ao fato de o tradutor não dominar suficientemente conotações e intertextos do texto original, ao passo que a tradução errada consciente existe quando, deliberadamente, o tradutor traduz incorretamente para confrontar a cultura ou aceitação dos leitores-alvo, podendo, para tal objetivo, introduzir forçosamente aspectos linguísticos e culturais estrangeiros. As terceira e quarta formas são tradução selecionada e compilação da tradução, retradução e adaptação. Entre as motivações para estas "traições criativas", há a necessidade de ser coerente com os hábitos e costumes do país receptor, sobretudo para satisfazer os gostos dos países receptores e para facilitar a disseminação ou, ainda, para atender conjunturas morais e políticas (146-7).

Xie ressalta que o tradutor, igualmente ao leitor, é um "receptor", Portanto, a relação do tradutor com o texto de partida é sempre dupla: receptor e emissor. Por outro lado, o leitor, igualmente ao tradutor, também é um agente da "traição criativa", pois são suas visões de mundo e suas experiências pessoais que darão vida e sentido às "traições criativas" do tradutor. Nesse sentido, o terceiro sujeito da "traição criativa" é o "ambiente de recepção" da obra. Em nosso entendimento sobre a proposição de Xie, a cadeia da "traição criativa" está completa quando se produz uma relação forte entre o que dispõe o autor, o tradutor (que propõe "traições criativas", o leitor (que, individualmente, dá sentido à "traição") e o ambiente de recepção (que, coletivamente, consagra as "traições”).

As proposições de Xie estão longe de serem consenso no meio acadêmico chinês, pois, como Zha and Tian (8) apontam, há um preconceito em tratar das "traições criativas" por elas não serem simplesmente um enfrentamento do tradutor ao texto-fonte, mas por explicitarem uma multiplicidade de posições enunciativas: a do autor, a do tradutor, a do leitor e, ainda, a do ambiente de recep- 
ção. Por isto, como defende Xie, na China a questão da tradução não poder ser mais vista apenas como o ressurgimento do processo psicológico original do autor, mas como a recriação desse texto em seus diferentes ambientes de recepção.

Feitas as contextualizações históricas sobre as línguas chinesas e a literatura, bem como a nossa breve apresentação de uma nova perspectiva teórica para a tradução literária no contexto chinês, passamos nas seções seguintes a tratar da poesia chinesa e de novas interpretações sobre traduzir poesia $d a$ ou para a China.

\section{Forma, poesia e tradução de poesia da e para a China: a quadratura do Círculo?}

The very nature of the Chinese language provides the special poetic for the poem. Chinese phrases are often devoid of an obvious subject/personal pronoun. Thus both $\mathrm{Du} F u$ and Yang Lian could climb the terrace. Chinese verbs have no tenses, therefore the monkeys could wail during both the Tang Dynasty and today. Chinese readers often have to add a prepositional phrase between images to create a linguistic link. There are no fixed relationships between the images - they continue one by one and level by level, until the portable universe focuses finally on a stained wine cup, held by a certain poet at a certain moment. The depth of this poetic is this open situation - the climbing includes all climbers. During that moment, space within the poem is created, time is canceled. We are sent into an eternal exile. (Yang Lian ${ }^{11}$ )

"Já se disse que traduzir poesia chinesa para um idioma ocidental seria algo tão impossível como a quadratura do círculo" (Campos 235). Pensando com Haroldo de Campos, onde residiria

${ }^{11}$ Disponível em http://yanglian.net/yanglian_en/essays/essays_01_12.html 
a "forma" da poesia (clássica) chinesa? Tomemos como exemplo o octeto regular (lüshï律詩) e o quarteto regular (juéju絕句), formas básicas na poesia do “Estilo Novo” (jìntǐshīi近體詩) e que foram reimaginadas por Haroldo de Campos em Escrito Sobre Jade. Especificamente, o quarteto regular traz em sua própria composição visual três dimensões físicas a serem consideradas: (i) a dimensão macrovisual, ou seja, a admiração da "quadratura" formada pela disposição uniforme dos caracteres mais a sua caligrafia; (ii) a dimensão microvisual, a beleza do caractere isolado mais a sua composição em radicais que poderão dialogar com outros caracteres ao longo do poema, potencializando os espaços para uma leitura (inter)semiótica do poema; e (iii) a dimensão do som e da rima. Nesta complexa relação de "formas", jogamos aqui com Haroldo ao propormos uma leitura em que a poesia chinesa é um círculo justamente por sua quadratura: um círculo imaginário multissensorial é formado numa leitura do poema em que se contemple, simultaneamente, todas as suas dimensões físicas. Paradoxalmente, a poesia clássica, em sua rigidez, é uma tela infinita para a materialização do poeta-pintor: ut pictura poesis.

Isocronamente às dimensões físicas do "Estilo Novo", residem, evidentemente, as questões da língua chinesa apontadas acima por Yang Lian, os jogos das "chinesidades" e, ainda, e tão importante quanto, a mensagem e o sentido do poema. Assim, traduzir poesia é flertar com o impossível e com o intraduzível, mas, como advertem, respectivamente, Paz (17) e Berman (32),

Feita de ecos, reflexos e correspondências entre o som e o sentido, a poesia é um tecido de conotações e, portanto, intraduzível. Confesso que essa ideia me repugna não só porque se opõe à imagem que faço da universalidade da poesia, mas porque se baseia em uma concepção errônea do que é a tradução.

Partir do pressuposto que a tradução é a captação do sentido, é separá-la de sua letra, de seu corpo mortal, de sua 
casca terrestre. É optar pelo universal e deixar o particular. A fidelidade opõe-se - como para o crente e o filósofo - à fidelidade à letra.

Assim sendo, pensar em uma poética do traduzir - ou transcriar e reimaginar - a poesia clássica deve ser refletida dentro da problemática da "quadratura do círculo" para, na inevitável confrontação com o "quimérico", traduzir o impossível. Pensando nessas possibilidades para o impossível, apresentaremos nas seções a seguir as metáforas do Taotie (Portugal) e da Paralaxe Tradutória (Jatobá) para, por fim, apresentar traduções de poesia da China ao Brasil e do Brasil à China que ilustrem essa "poética do traduzir".

\section{Chinesidades e Brasilidades: Antropofagias tradutivas complementares?}

\section{A metáfora do Taotie 饕䬸}

Ricardo Portugal, poeta brasileiro e eminente tradutor de poesia clássica chinesa, ao refletir sobre o seu traduzir, propôs a metáfora do Taotie 饕䬸 ${ }^{12}$, não como um conceito prescritivo para o seu ato tradutório, mas sim como "uma espécie de 'emblema', portanto, imagem-ícone - necessariamente exagerada" (Portugal). Apesar de a metáfora do Taotie dialogar com a Antropofagia e Haroldo, Portuga ${ }^{13}$ ressalta:

A proposta, claro, envolve uma referência 'lateral' ou sutil à Antropofagia, conceito-chave, inaugurativo, do Mod-

\footnotetext{
${ }^{12} \mathrm{O}$ Taotie é um lendário monstro canibal da mitologia chinesa e em função do seu voraz apetite é referido como "besta glutona" ou "ogro glutão". De acordo com lendas, apesar de mastigar corpos não era capaz de degluti-los, cuspindo-os após deformá-los com sua mastigação.

13 Em entrevista concedida para os autores do presente artigo. Por oportuno, agradecemos a valiosa ajuda de Ricardo Primo Portugal e de Leandro Durazzo na discussão e aprofundamento de algumas das ideias abordadas neste artigo.
} 
ernismo brasileiro, o qual se propõe resolver o primeiro problema crucial da arte brasileira: como construir uma produção própria (específica do Brasil, única, diferenciada, característica da cultura 'nacional') em um país no qual a cultura combina necessariamente a assimilação das correntes internacionais (suas teorias e práticas): 'devorar' a arte estrangeira é diferente de 'imitar'; é preciso inventar algo novo e singular. Daí a poesia será sempre invenção, e a tradução também. A tradução deve construir uma nova forma, um novo objeto. Quando se lê Haroldo de Campos, nota-se que seu pensamento aponta para a Antropofagia, é uma continuação do paradigma modernista 'radical', PauBrasil-Antropofágico (conforme era levado por Oswald e Mário de Andrade, entre outros). (idem)

Para Portugal, apesar de o canibalismo do Taotie ter paralelos com a antropofagia, é necessário destacar que um ponto fulcral da metáfora e, portanto, de seu processo tradutório com um poeta-tradutor, não é a possibilidade de uma apropriação para (re)criar a poesia, mas, sim, de aceitar a "deformação" como o resultado desta impossibilidade de deglutir o outro. Como elucida o poeta, o Taotie:

[...] é um 'antropófago frustrado'. Ele come, mas nunca devora totalmente; deforma, mas não elimina, e sua criação é sempre híbrida, estranha, questionável e infeliz. [...] E, afinal, sua obra é 'monstruosa', não é? Cria objetos 'deformados': nem tão chineses, nem tão brasileiros. Mas a questão é que só assim funcionam bem, isto é: se o poema ficar, em português, algo muito 'normal' ou 'comum', reconhecível pelo leitor como o tipo de poesia que todo mundo encontra por aí em qualquer jornal (a fórmula contemporânea de normalização: versinhos livres e de compreensão fácil, etc... 'diluição' do modelo modernista), então a intenção poética do autor original quase se perde. Em minha prática de tradução, procuro conscientemente produzir objetos que 
tenham formas próprias e únicas, diferenciadas, utilizar-me dos recursos formais e referências semânticas disponíveis em minha cultura para reproduzir os significados do autor original, o efeito da forma que ele construiu em sua cultura. $\mathrm{O}$ objeto tem que ser estranho o bastante, para que seja único. Por exemplo, traduzo $\mathrm{Du} F u$ procurando, por vezes, fazê-lo soar como 'um Camões estranho'. (Idem)

Apesar dos paralelos entre o canibalismo do Taotie e a antropofagia, o Taotie se diferencia no sentido dos resultados oriundos de seus desejos e fomes. A "deformação" provocada pela mastigação do Taotie não é oriunda de uma fome de apropriação do objeto e de que ele permaneça estruturalmente. $\mathrm{Na}$ antropofagia haroldiana, a fome "[...] implica um desejo de fazer com que o outro ao ser alterado permaneça estruturalmente; enquadrando-o na episteme da semiótica europeia e seu pressuposto formalista do primado do significante" (Faleiros 37).

Tentando estabelecer paralelos e conexões entre essas maneiras de pensar a tradução como espaço híbrido, além de antropófaga modernista, a tradução guardaria correlações com modos de captura, deglutição e incorporação do diferente, por meio das quais uma "fidelidade à letra" (cf. Berman), fidelidade possível ao corpo mortal do poema, encontra-se assegurada. É a isso que se refere Faleiros quando, pensando com a etnologia ameríndia de Viveiros de Castro, afirma:

Traduzir é vingar-se no sentido ameríndio. Não porque se queira pensar o nacional ou operar uma devoração crítica, assimilando as qualidades do outro para fortalecer-se. Mas porque devorar, e ser devorado, é garantir a persistência de uma relação com os inimigos (com Outrem). (Faleiros 39)

Por fim, o Taotie pode servir de paralelo também aos Fantasmas Famintos, criaturas de um dos reinos da cosmologia budista. 
Os fantasmas famintos são aqueles que têm grandes estômagos e pescoços muito finos, razão pela qual não conseguem jamais saciar sua fome, não importando o quanto tentem devorar. A antropofagia - modernista, mas também tradutório no sentido haroldiano que Portugal descreve - talvez se assemelhe a isso: sem se dar por satisfeito, recria em sua própria tessitura o corpo mortal do poema que, de origem, foi escrito em outro idioma. Taotie e o antropófago insaciável seriam, desse modo, espelhos metafóricos para pensarmos o processo da tradução, sobretudo em sua dimensão literária. Jamais completa, jamais resolvida em definitivo, a tradução mastiga e rumina o outro - o corpo do poema estrangeiro - para tentar daí tirar algum suco, algum nutriente para seu próprio organismo - para sua própria literatura vernácula, poderíamos dizer. Ao mastigar o diferente, a tradução modifica ambos: a si, porque incorpora e reelabora suas próprias possibilidades expressivas; ao outro, porque o transforma, deforma, destrói e reconstrói a partir de um espelho transcriado, expandindo assim seu raio de alcance e apreciação.

Título: Representações zoomórficas de Taotie.

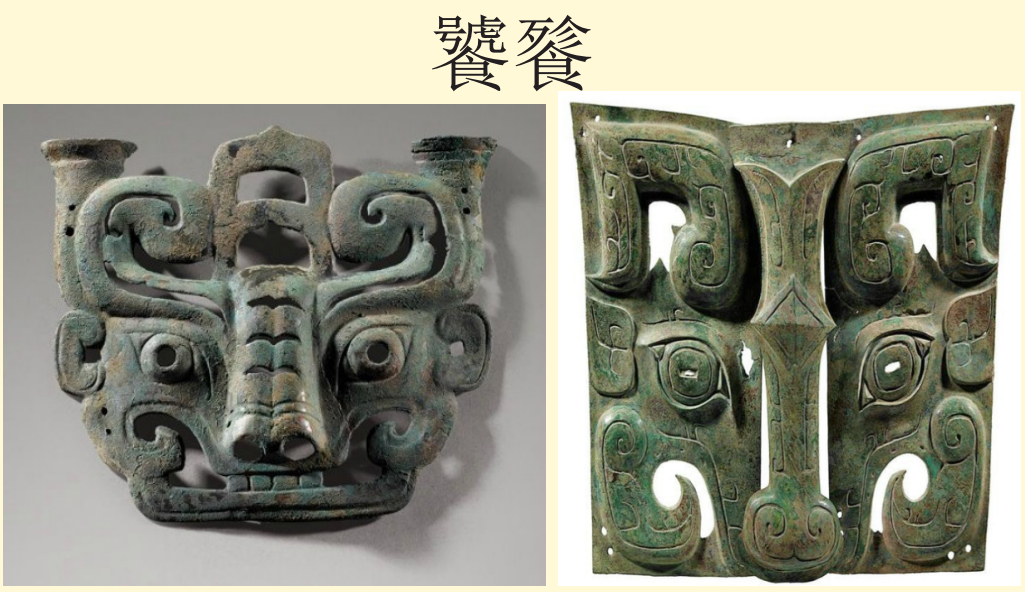




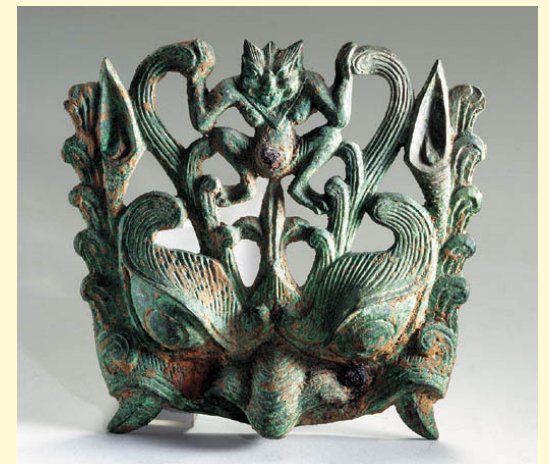

Fonte: desconhecida

\title{
Traduzir poesia chinesa: Uma Paralaxe tradutória
}

\begin{abstract}
Um país que se autoconsome, fechado em sua própria paralaxe, perdido em seus símbolos e em sua própria busca por re-simbolizações do seu momento - híbrido, pulsante e reflexo do nosso mundo globalizado em uma simbiose capitalista-comunista paradoxal: a China invade o Ocidente ou o Ocidente que invade a China? Esse momento é a concretização do modelo global-consumidor criado pela Inglaterra, divulgado nos quatro cantos do mundo pelos EUA e, enfim, posto em prática pelo poderio industrial e populacional da China. (Jatobá “A paralaxe chinesa” 12 itálicos originais)
\end{abstract}

A palavra paralaxe, ou lacuna paraláctica, pode ser também entendida, tomando as palavras de Slavoj Žižek, como:

[...] a ilusão de poder usar a mesma linguagem para fenômenos mutuamente intraduzíveis e que só podem ser compreendidos a partir de uma espécie de visão em paralaxe, de um ponto de vista sempre mutável entre dois pontos entre os quais não há síntese nem mediação possível (Žižek 14). 
Para entender o momento chinês, portanto, restam-nos duas alternativas. Ou voltamos um passo precavido para trás, para ampliar o enquadramento que observamos e, assim, evitarmos o erro de paralaxe; ou aceitamos a paralaxe em suas idiossincrasias, pois mesmo o texto original não é o real, sendo antes uma fotografia do tempo-espaço do autor. No processo tradutório, os textos de partida e de chegada são como fotografias em que um conjunto de cascas visíveis e sensíveis surgem pertencentes a tempo-espaços naturalmente não reproduzíveis, quer no contexto de origem, quer no contexto traduzido.

Assim, cabe ao fotógrafo-tradutor sentir o impacto-efeito da imagem "original" verbalizada e não-verbalizada para que este produza com a sua bagagem estética, (inter)semiótica e gramatical uma nova imagem que, por ser naturalmente diferente da "original", é a única que poderá reproduzir o "impacto-efeito" na cultura de chegada; ou seja, a única a conseguir restaurar as imagens do texto de partida. Eis o paradoxo da paralaxe tradutória: é a visão em paralaxe do tradutor que compreende os textos de partida e de chegada em uma só humanidade possível - a literatura como a arte de traduzir sentimentos em imagens estáticas, sistemáticas e sequencialmente organizadas para a produção de imagens mentais em movimento.

A paralaxe faz com que a foto traduzida pelos nossos olhos seja diferente da vista pelas lentes. O paradoxo é que apenas a paralaxe da tradução possibilita a (re)produção dos efeitos, portanto dos impactos a serem lidos. A questão é: a paralaxe está tanto nas dimensões-visuais de um texto (diagramação, tipografia, estrutura linguística) como nas suas dimensões não-visuais (estilo tom, mensagem, impacto-efeito). Por um lado, as questões visuais, objeto de maior interesse neste artigo, são mais óbvias, e, por outro lado, as dimensões não-visuais se tornam menos óbvias ou perceptíveis. Reduzir nossa análise ao visual não resolve o problema da paralaxe, mas ajuda-nos a entendê-la melhor. Para isso, com o intuito de ilustrar algumas possibilidades de pensar a paralaxe em sua dimensão visual, vejamos abaixo Paulo Leminski, por Lang Sida, Li Bai, por Júlio Jatobá, e Bai Juyi, por Ricardo Portugal e Tan Xiao. 


\section{Paulo Leminski 保罗・莱明斯基 (1944 - 1989)}

\author{
coração \\ EM CIMA \\ escrito embaixo \\ FRÁGIL
}

心

向上 $\uparrow \uparrow$

下写

易碎!

\section{Paulo Leminski 保罗 • 莱明斯基}
$\mathrm{Se}$
nem
for
terra
Se
trans
for
mar

如果

不再是陆地, 如果

变成 海洋。

\section{Libai 李白 (701-762)}

清平調

雲想衣裳花想容

春風拂檻露華濃

若非群玉山頭見

會向瑤台月下逢
A Yang Guifei

nuvens seu vestido

flores sua face

primavera

roça varandas

orvalho cristaliza flores

se não a vejo ao cume da montanha 


\section{花非花}

Bai Juyi 白居易 (772-846)

花非花

霧非霧

夜半來

天明去

來如春夢幾多時

去似朝雲無䍃處 flor não flor

névoa não-névoa

noite-meia vem

dia raia vai-se

vem na primavera tantas vezes sonho

foi-se manhã cedo nuvem se dissolve

Considerada a paralaxe tradutória, não se trata de perder ou ganhar. Poesia é fotografia. Assim como, na China clássica, poesia, pintura, caligrafia e trabalho burocrático compunham um grande corpo de apreensão - inclusive estética - das expressões artísticas experimentadas pelos letrados. Assim como na fotografia, mesmo que se reproduza fielmente a cena e a luz, não se reproduz a foto original; a nova imagem-poesia nunca será uma cópia, e nem deveria ou gostaria de ser. Ela é um misto da leitura de imagens mentais do coletivo e do individual, ou seja, não é nada mais que um enquadramento consciente, criativo e espacial e temporalmente situados da íntima relação da tríade poesia-tradutor-leitor (nenhum funciona isoladamente, pois são relações complementares). Mais que isso, a paralaxe não é resultado apenas da nova imagem-poesia pensada pelo tradutor-fotógrafo, mas existe no próprio enquadramento que o leitor terá do poema ou da forma poética.

Portanto, a paralaxe tradutória nunca é perda, ao contrário, ela é sempre a possibilidade de ganhar no exercício da alteridade, de enxergar e perceber (ou não) o próximo através da poesia, seja na forma, seja no som, seja na emoção, seja no sentido. Enfim, a 
paralaxe é natural e intrínseca ao processo poético. Com a consciência da paralaxe tradutória cabe ao tradutor uma tomada de atitude perante a alteridade. A paralaxe, a nosso ver, localiza-se no trabalho fronteiriço da cultura. E como aponta Homi Bhabha:

\begin{abstract}
O trabalho fronteiriço da cultura exige um encontro com 'o novo' que não seja parte do continuum de passado e presente. Ele cria uma idéia do novo como ato insurgente de tradução cultural. Essa arte não apenas retoma o passado como causa social ou precedente estético; ela renova o passado, refigurando-o como um 'entre-lugar' contingente, que inova e interrompe a atuação do presente. O 'passadopresente' torna-se parte da necessidade, e não da nostalgia, de viver. (Bhabha 27)
\end{abstract}

A tradução literária, nesse caso, seria algo como transpor um guzheng 古筝 ${ }^{14}$ a um violão, dois instrumentos de grande beleza musical, ainda que particulares e singulares. O primeiro, como a língua chinesa, de natureza tonal e de escalas tonais de difícil reprodução; o segundo, como a língua portuguesa, de natureza melódica bem delimitada, oitavada e trasteada. Consideradas as especificidades dos sistemas linguísticos para os quais se traduz, o que fazer para dar conta das singularidades do corpo textual do original (sua sonoridade, síntese, cadência tonal etc.)? Usa-se um violão de 7 cordas para compensar? Uma guitarra portuguesa?

Por fim, a paralaxe tradutória aproxima-se da ideia de Frost, para quem "a poesia é aquilo que se perde na tradução". Porém, não defendemos que "a poesia é o que se perde na paralaxe". Antes, a poesia é uma possibilidade do que se vê fora da paralaxe. E para isso o processo de tradução, variação e ampliação de expedientes estilísticos torna-se fundamental.

14 Instrumento musical chinês que é considerada o instrumento ancestral das diversas cítaras asiáticas.

Cad. Trad., Florianópolis, v. 39, n $^{0}$ esp., p. 120-147, set-dez, 2019 


\section{Considerações finais}

[...] o estatuto da impossibilidade. Para quem aborda o ato de traduzir poesia sob a categoria da criação, essa superlativação das dificuldades que lhe são intrínsecas só pode acrescerlhe, na medida proporcional, o fascínio. (Campos 235)

Nestas breves linhas traçamos algumas considerações iniciais para uma poética do traduzir $a$, na e para a China. Concentramos nossa proposta na tradução de literatura, mais especificamente, de poesia, de e para a língua chinesa. Seria presunçoso e, inclusive, arrogante afirmar que tão ousada empreita pudesse ser iniciada e finalizada nas dimensões deste texto. Levando em conta a imensidão de (inter)textos sobre a história da literatura chinesa e, ainda, a vastidão das possibilidades de abordá-las em diferentes pontos de vista metodológicos e teóricos, seria impossível oferecer ao leitor(a) base sólida sobre o que poderá vir a ser a "escola chinesa de tradução". Assim sendo, sem dúvida da emergente necessidade de aprofundar o tema, resumimos abaixo algumas de nossas considerações sobre a proposição de uma "poética do traduzir".

O discurso de uma "poética de traduzir a China" é, além de um projeto universal, algo localizado em tempo-espaços e em espaços-geográficos que ora convergem, ora divergem. Além do espaço da alteridade entre poesia chinesa e brasileira per se, há o espaço das alteridades do(s) poeta(s), do(a) leitor(a) em língua chinesa, do(a) tradutor(a), do(a) leitor(a) em língua portuguesa e, ainda, do(a) leitor(a) bilíngue. Desse modo, para o poema ganhar a dimensão de poesia-mundo, é preciso pensar que poemas são poesia-imagem cristalizadas; vistas e ouvidas sempre de diferentes ângulos. A poesia chinesa não se fecha em si, ao contrário, ela só existe fora de si; sua materialização e, consequentemente, sua tradução, são complexas cadeias de traições criativas e paralaxes tradutórias.

Retomando a metáfora do Taotie, Brasil e China são monstros que se devoram e se mastigam sem poderem mutuamente se deglu- 
tirem para, paradoxal e metafisicamente, se retro-alimentarem a fim de produzir em suas alteridades não apenas uma poesia nova, mas sim uma nova poética do traduzir. Somente neste exercício de aceitar a impossibilidade de ser o outro é que se pode ser capaz de imaginar (e criar) um jueju haroldiano ou chinesidades leminskianas que produzam o estranhamento necessário para sentir o espírito e a força de nossas poesias. Eis as apropriações que (per)fazem a quadratura do círculo ou, em nosso ver, uma inevitável e necessária paralaxe tradutória. Enfim, uma "poética do traduzir" criativa, consciente e (im)permanente. Poesia é imagem, traduzir é alteridade.

\section{Referências}

"Biografia de Gu Kaizhi (incluída na 62.a Série Biográfica (rolo 92) de Fang Xuanling 房玄齡)." O Livro de Jin (Jin shu 晉書). Pequim: Zhonghua Shuju, 1974. 2404-06.

Berman, Antoine. tradução e a letra ou o albergue do longínquo. Tradução de Furlan, Mauri, Marie-Hélène Catherine Torres and Andréia Guerini. Rio de Janeiro: 7Letras/PGET, 2007, 2007.

Bhabha, Homi. O local da cultura. Tradução de Myriam Ávila, Eliana Lourenço de Lima Reis e Gláucia Renate Gonçalves. Belo Horizonte: Editora da UFMG, 1998.

Campos, Haroldo de. "Minha relação com a poesia chinesa". Revista de Cultura 1995: 231-41.

Cheung, Martha P. Y. "Introduction: An Anthology of Chinese Discourse on Translation". In: Cheung, Martha P. Y. An Anthology of Chinese Discourse on Translation: From Earlist Times to the Buddhist Project. Vol. 1. London \& New York: Routledge, 2014[2006]. 268. 
Escarpit, Robert. Sociologie de la Littérature (The Sociology of Literature). Tradução de Wang Meihua (王美华) and Yu Pei (于沛). Hefei: Anhui Literature \& Art Publishing House, 1987.

Faleiros, Álvaro. Traduções canibais: uma poética xamânica do traduzir. Florianópolis: Cultura e Barbárie, 2019.

Jatobá, Júlio Reis. “A paralaxe chinesa”. In: . Monteiro, Arthur and Isabela Lyrio (Eds). O Império do Meio. Brasilia: Esterográfica, 2015.

Jatobá, Júlio Reis. "Poesia e (in)traduzibilidade na língua chinesa". Scientia Traductionis.13, Florianópolis, (2013): 213-23. Disponível em: < https:// periodicos.ufsc.br/index.php/scientia/article/view/30271 >. Acesso em: 24 out 2019

Liao, Hong Jun, (ed). 中西比较文学手册 [Manual da Literatura Comparativa Chinesa e Ocidental]. Shanghai: Sichuan People's publishing House, 1987.

Paz, Octavio. Tradução: literatura e literalidade. Tradução de Doralice Alves de Queiroz. Belo Horizonte: FALE/UFMG, 2009.

Portugal, Ricardo Primo. "Antologia da poesia chinesa - Dinastia Tang; Poesia completa de Yu Xuanji: um percurso de transcriação em português”. Crossings: Brazil, Portugal and Greater China. 2015. [No Prelo]

Pozzana, Claudia e Alessandro Russo. “Esta é uma outra China”. Tradução de Andréia Guerini. Poesia Sempre 2007: 5.

Sinedino, Giorgio. “As Dimensões do Cânone-VII: Os três prefácios da classificação dos poetas, por Zhong Rong - tradução, notas e comentário". Revista de Cultura 2017: 132-54.

Sinedino, Giorgio. "O Poeta-Pintor no Seu Meio: Um Relance sobre Gu Kaizhi - Seleção de Fontes Biográficas e Ensaios.” Revista de Cultura 2017: 128-54.

Sinedino, Giorgio. "Ut Pictura Poesis: Intuições para a Experiência Chinesa Um Esboço.” Revista de Cultura 2017. 
Xie, Tianzhen. "Medio-Translatology: A New Area of Comparative Literature." Revue de littérature comparée 337.1 (2011): 42-48. CAIR.INFO. Disponível em: <https://www.cairn.info/revue-de-litterature-comparee-2011-1-page-42.htm > . Acesso em: 25 out 2019

Xie, Tianzhen. "Medio-Translatology: New Perspectives on Comparative Literature and Translation Studies." Comparative Literature: East \& West 1.1 (2017): 125-33. Routledge. Disponível em: .<https://www.researchgate. net/publication/321222008_Medio-translatology_New_Perspectives_on_ Comparative_Literature_and_Translation_Studies > Acesso em: 25 set 2019

Xie, Tianzhen. 译介学 [traduto(meio)logia]. Shanghai: Shanghai waiyu jiaoyu chubanshe, 1999.

Yang, Lian. “中文之内[Dentro da língua-cultura chinesa]”. Yang Lian. Disponível em: < http://yanglian.net/yanglian/pensee.html > . Acesso em: 25 set 2019

Zha, Mingjian e Yu Tian. “从译者文化地位的边缘化谈起 [On the Subjectivity of the Translator].” Chinese Translators Journal 24.1 (2003): 19-24.

Zhang, Jianbo. “Tradução de Obras de Jorge Amado: Um Estudo de Relações entre Tradução e Poder." Tese de doutoramento em Estudos Literários. Universidade de Macau, 2018.

Žižek, Slavoj. A visão em paralaxe. Tradução de Maria Beatriz de Medina. São Paulo: Boitempo editorial, 2015.

Recebido em: 05/10/2019

Aceito em: 22/11/2019

Publicado em dezembro de 2019

Júlio Reis Jatobá. E-mail: juliojatoba@um.edu.mo

ORCID: https://orcid.org/0000-0001-5669-8119 